Int. J. Plant Sci. 165(4 Suppl.):S23-S33. 2004.

(c) 2004 by The University of Chicago. All rights reserved.

1058-5893/2004/1650S4-0003\$15.00

\title{
PLANT DISPERSAL ACROSS THE TROPICAL ATLANTIC BY WIND AND SEA CURRENTS
}

\author{
Susanne Renner ${ }^{1}$ \\ Department of Biology, University of Missouri, St. Louis, Missouri 63121, U.S.A.; and Missouri Botanical Garden, \\ St. Louis, Missouri 63166, U.S.A.
}

\begin{abstract}
This review brings together evidence on the monophyly and ages of angiosperm lineages ranging across the tropical Atlantic with data on the direction, strength, and speed of sea currents and wind jets across that ocean. Mainly for pragmatic reasons (data availability), the focus is on genera, which introduces a rank-based constraint into the analysis. However, trans-Atlantic disjunctions at the genus level seemed more likely to be attributable to long-distance dispersal than those involving families or species; family-level disjunctions often may date back to the breakup of Africa and South America, and species-level disjunctions often may be anthropogenic. At least 110 genera (listed in this article) contain species on both sides of the tropical Atlantic. Molecular phylogenies and age estimates from molecular clocks are available for 11 disjunct genera, tribes, and species. Inferred directions and modes of dispersal can be related parsimoniously to water currents between Africa and South America and to exceptional westerly winds blowing from northeastern Brazil to northwest Africa. Based on diaspore morphology and inferred dispersal biology in the 110 genera, transAtlantic dispersal by water (in both directions) appears more common than dispersal by wind or on birds. Wind dispersal appears to have occurred in the direction from South America to West Africa but rarely in the opposite direction.
\end{abstract}

Keywords: Atlantic equatorial currents, biogeography, floating islands, Gondwana breakup, transatlantic dispersal, wind dispersal.

\section{Introduction}

In an important review of tropical trans-Atlantic and trans-Pacific range disjunctions in the seed plants, Robert Thorne (1973) tabulated examples of species, genera, subfamilies, and families distributed on both sides of the tropical Atlantic. Thorne's overall goal was to assess the relative roles of Gondwana breakup compared with long-distance dispersal as causes of trans-Atlantic disjunctions. He was writing before the extent of Tertiary floristic connectivity across Beringian and North Atlantic land bridges was fully recognized (Wolfe 1975; Tiffney 1985a, 1985b; Manchester 1999) and therefore did not consider entry of lineages from the north as a third conceivable explanation for disjunct ranges between Africa and South America. That this is a real possibility is shown by phylogenetic and paleobotanical results for sublineages of legumes, Lauraceae, Malpighiaceae, and Melastomataceae (Lavin and Luckow 1993; Lavin et al. 2000; Chanderbali et al. 2001; Renner et al. 2001; Davis et al. 2002).

In the absence of information from fossils representing a taxon on both sides of the Atlantic, Thorne used taxonomic rank as a proxy for age, arguing that while it is a "truism that evolutionary rates vary greatly among different organisms," nonetheless, species formation "surely takes

\footnotetext{
${ }^{1}$ Current address: Systematische Botanik, Ludwig-MaximiliansUniversität, Menzinger Strasse 67, D-80638 Munich, Germany; e-mail renner@lrz.uni-muenchen.de.
}

Manuscript received August 2003; revised manuscript received January 2004. place much more rapidly than the evolution of genera, tribes, subfamilies, families, or even higher categories" (Thorne 1996 , p. 189). Flowering plant species and genera often will be younger than 95 million years, making it likely that their presence on both sides of the Atlantic results from dispersal across that ocean. Disjunctions involving taxa at higher hierarchical levels were seen as more readily attributable from the breakup of South America and Africa. Conversely, many of the 108 species that occur in West Africa as well as in tropical America and that are mostly aquatics, maritime species, or herbaceous weeds were suspected to have reached their ranges via anthropogenic invasion.

Thorne (1973) found 111 genera that are restricted or almost restricted to South America, Africa, and Madagascar, and these form the core of his assessment that long-distance dispersal plays a small but important role in the evolution of the floras on both sides of the Atlantic. This article follows this line of thought and concentrates on genera and species. It goes beyond previous reviews of disjunct taxa (Engler 1905; Good 1964; Hepper 1965; Thorne 1972, 1973) in addressing a question that has only come within reach with the advent of DNA sequence data. Can we begin to infer the timing and direction of dispersal events in the past? With sufficient estimates (based on calibrated genetic distances, i.e., molecular clocks) we expect to see patterns in time and direction of transoceanic dispersal events because wind and water circulation systems are not randomly distributed in space and time. They should leave an evolutionary trace, provided they existed long enough to override lineage-specific differences in establishment capability (for an example, see Muñoz et al. 2004). Ideally, it should eventually become possible to use 


\section{Table 1}

Genera with Range Disjunctions between South America and Africa

\begin{tabular}{|c|c|c|c|c|}
\hline Family, genus, and author & No. of total species & No. of Neotropical species & No. of African species & References and comments \\
\hline \multicolumn{5}{|l|}{ Acanthaceae: } \\
\hline Barleria & 300 spp., mainly Africa/Asia & 1? B. oenotheroides & 200? B. oenotheroides & $\begin{array}{l}\text { LDD dispersal from Africa to Neotropics; } \\
\text { Balkwill and Balkwill } 2002\end{array}$ \\
\hline Dicliptera Juss. & $100 ?$ & $84 ?$ & 16 & L. McDade, pers. comm., 2003 \\
\hline Lepidagathis Willd. & 100 ? & 1 & 24 & L. McDade, pers. comm., 2003 \\
\hline Mendoncia Vell. & 60 & 52 & 5 & T 73 \\
\hline \multicolumn{5}{|l|}{ Achariaceae (ex Flacourtiaceae): } \\
\hline Lindackeria C. Presl & 19 & 13 & 6 & Т 73 \\
\hline \multicolumn{5}{|l|}{ Annonaceae: } \\
\hline Annona L. & 117 & 108 A. glabra & 10 A. glabra, coastal West Africa & T 73; seawater dispersed; Smith 1981; Meyer 2000 \\
\hline \multicolumn{5}{|l|}{ Apocynaceae: } \\
\hline Malouetia A. DC. & 25 & 21 & 2-3, West Africa & $\begin{array}{l}\text { T 73; } 1 \text { species water dispersed, several others wind } \\
\text { dispersed; M. Endress, pers. comm., } 2003\end{array}$ \\
\hline \multicolumn{5}{|l|}{ Araceae (ex Lemnaceae): } \\
\hline Wolffiella Hegelm. & 10 & 6 W. welwitschii & 1 W. welwitschii & $\begin{array}{l}\text { T 73; repeated LDD by seawater; Kimball et al. } \\
2003\end{array}$ \\
\hline \multicolumn{5}{|l|}{ Arecaceae: } \\
\hline Elaeis Jacq. & 2 & 1 E. guineensis & 1 E. guineensis & T 73; W. Hahn, pers. comm., 2002 \\
\hline Raphia P. Beauv. & 21 & 1 R. taedigera & 20 R. taedigera & T 73; LDD by seawater; Urquhart 1997 \\
\hline \multicolumn{5}{|l|}{ Asteraceae: } \\
\hline Achyrocline (Less.) DC. & 20 & 16 & 3 & T 73; J. Panero, pers. comm., 2003 \\
\hline Aspilia Thouars (close to Wedelia) & 60 & 40 ? & 20 ? & T 73; J. Panero, pers. comm., 2003 \\
\hline Coreopsis L. (close to Bidens) & 115 & 76 & 39 & T 73; J. Panero, pers. comm., 2003 \\
\hline Jaumea Pers. & $2 ?$ & 2 & 1 & $\begin{array}{l}\text { T 73; African Hyptis spicigera, a tidal saltmarsh } \\
\text { halophyte }\end{array}$ \\
\hline Stenocline DC. & 6 & 4 & $2 ?$ & T 73 \\
\hline \multicolumn{5}{|l|}{ Brassicaceae (ex Capparaceae): } \\
\hline Cleome L. & $150-200$ & $100-150$ & 50 C. afrospina & $\begin{array}{l}\text { LDD dispersal of C. afrospina but not the other } \\
\text { species; Iltis } 1967\end{array}$ \\
\hline \multicolumn{5}{|r|}{ species; iltis 170 / } \\
\hline Pitcairnia L’Hér. & 260 & 260 & 1 & $\begin{array}{l}\text { T 73; LDD to West Africa by wind; Givnish et al. } \\
2004\end{array}$ \\
\hline \multicolumn{5}{|r|}{$\cos$} \\
\hline Commiphora Jacq. & 190 & 2 & 145 (excluding Madagascar) & LDD to South America; Weeks et al. 2004 \\
\hline \multicolumn{5}{|l|}{ Cactaceae: } \\
\hline Rhipsalis Gaertn. & 50 & 50 R. baccifera & 1 R. baccifera & T 73 (mentioned only in text) \\
\hline \multicolumn{5}{|l|}{ Chrysobalanaceae: } \\
\hline Chrysobalanus L. & $1-2$ & C. icaco & C. icaco & $\begin{array}{l}\text { T 73; invasive in Pacific Islands and Hawaii, LDD } \\
\text { by seawater }\end{array}$ \\
\hline Hirtella L. & 103 & 102 & 1 East Africa (!) & T 73 \\
\hline \multicolumn{5}{|l|}{ Clusiaceae: } \\
\hline \multicolumn{5}{|l|}{ Garcinia L. (including } \\
\hline Rheedia L.) & 300 & Needs study & Needs study & $\begin{array}{l}\text { T 73; species circumscriptions and relationships } \\
\text { very unclear; P. Sweeney, pers. comm., } 2002\end{array}$ \\
\hline Symphonia L.f. & 17 (16 in Madagascar) & 1 S. globulifera & 1 S. globulifera & $\begin{array}{l}\text { T 73; LDD by seawater from Africa to Neotropics; } \\
\text { Dick et al. } 2003\end{array}$ \\
\hline \multicolumn{5}{|l|}{ Combretaceae: } \\
\hline Conocarpus L. & 2 & 2 C. erectus & 1 C. erectus & T 73; mangrove species \\
\hline
\end{tabular}


Laguncularia C.F. Gaertn.

Commelinaceae:

Buforrestia C. B. Clarke

Convolvulaceae:

Calycobolus J. A. Schultes

Legendrea Webb \& Berthel

Cucurbitaceae:

Cayaponia Silva Manso

Dichapetalaceae:

Tapura Aublet

Eriocaulacaceae:

Syngonanthus Ruhland

Euphorbiaceae:

Amanoa Aublet

Caperonia A. St.-Hil.

Maprounea Aublet

Pogonophora Benth.

Tetrorchidium Poepp. \& Endl.

Fabaceae:

Andira Juss.

Copaifera $\mathrm{L}$.

Desmanthus Willd.

Drepanocarpus G. Mey. =

Machaerium Pers.

Guibourtia Benn.

Haematoxylum $\mathrm{L}$.

Hymenaea L.

Parkinsonia L.

Pentaclethra Benth.

Pomaria Cav.

Gelsemiaceae (ex Loganiaceae):

Mostuea Didrichsen

Gentianaceae:

Neurotheca Benth.

Schultesia Mart.

Voyria Aublet

Hernandiaceae:

Gyrocarpus Jacq.

Hernandia L.

Humiriaceae:

Sacoglottis Mart.

Lamiaceae:

Hyptis Jacq.

Lauraceae:

Ocotea Aublet
1 L. racemosa

1, Guianas

$45-60$

196

16

20

29

120

20-25

19

2
15

3

20 (also Polynesia, Australia)

195

30

3

28 A. inermis

26

2

2

15

1

9

? H. spicigera
L. racemosa

2

1

1

2

120 M. lunatum

12, New World

1 N. loeselioides

14 S. stenophylla

3, but G. americanus polyphyletic

2 H. spicigera Hayne

18
T 73; mangrove species

T 73; LDD very likely; R. Faden, pers. comm., 2002

T 73

T 73

T 73

T 73

T 73; LDD by wind from South America to Africa?

T 73; H.-J. Esser, pers. comm., 2002

T 73

T 73; Esser 1999

T 73; H.-J. Esser, pers. comm., 2002

T 73; H.-J. Esser, pers. comm., 2002

T 73; LDD by seawater; Pennington 2003 T 73

M. Lavin, pers. comm., 2002

LDD; Lavin et al. 2000, p. 459

T 73

T 73

Lee and Langenheim 1975; T. Penington, pers.

comm., 2003

sp., previously in Trachylobium

4, southern and northeastern Africa

3, southern Africa

T 73

T 73

Simpson 1998, 1999; B. Simpson, pers. comm.

1 N. loeselioides

1 West Africa S. stenophylla

T 73

T 73; age unknown; Struwe et al. 2002, p. 220

T 73; LDD likely; Struwe et al. 2002, p. 220

T 73; Albert and Struwe 1997; Struwe et al. 2002,

p. 266

Repeated LDD by seawater; S. Renner and

B. Zhang, unpub. MS

LDD from Neotropics to Bioko by seawater Kubitzki 1969

T 73; LDD of ancestor of African S. gabonensis by seawater

T 73

T 73; Chanderbali et al. 2001 
Table 1

(Continued)

\begin{tabular}{|c|c|c|c|c|}
\hline Family, genus, and author & No. of total species & No. of Neotropical species & No. of African species & References and comments \\
\hline \multicolumn{5}{|l|}{ Lentibulariaceae: } \\
\hline Utricularia $\mathrm{L}$. & 180 worldwide & $\begin{array}{l}\text { Needs study, } \\
\text { U. juncea }\end{array}$ & $\begin{array}{l}\text { Needs study, } \\
\text { U. juncea }\end{array}$ & Taylor 1989; Dörrstock et al. 1996 \\
\hline \multicolumn{5}{|l|}{ Malpighiaceae: } \\
\hline Heteropterys Kunth & 120 & 119 H. leona & 1, coastal West Africa H. leona & $\begin{array}{l}\text { T 73; probably introduced by man; Anderson 1990, } \\
2001\end{array}$ \\
\hline Stigmaphyllon A. Juss. & 90 & 89 & 1, West Africa & $\begin{array}{l}\text { T 73; S. bannisterioides probably introduced by } \\
\text { man; Anderson } 1990,1997\end{array}$ \\
\hline \multicolumn{5}{|l|}{ Malvaceae: } \\
\hline Carpodiptera Griseb. & 6 & 4 & 2 & Т 73 \\
\hline Ceiba Mill. & 1 & 1 C. pentandra & 1 C. pentandra & $\begin{array}{l}\text { LDD from Neotropics to Africa; C. Dick, pers. } \\
\text { comm., } 2003\end{array}$ \\
\hline Christiana DC. & $4-5$ & 2 C. africana & 1 C. africana & Т 73 \\
\hline \multicolumn{5}{|l|}{ Marantaceae: } \\
\hline Thalia L. & 7 & 7 T. geniculata & 1 T. geniculata & T 73; LDD by seawater \\
\hline \multicolumn{5}{|l|}{ Mayacaceae: } \\
\hline Mayaca Aublet & 4 & 3 & 1 & $\mathrm{~T} 73$; invasive aquatics \\
\hline \multicolumn{5}{|l|}{ Meliaceae: } \\
\hline Carapa Aublet & $2-7$ & ? C. guianensis & ? C. guianensis & $\begin{array}{l}\text { T 73; LDD from Africa to Neotropics, drifting } \\
\text { seeds; Gunn } 1968\end{array}$ \\
\hline Guarea L. & 40 & 35 & 5 & T 73 \\
\hline \multicolumn{5}{|l|}{ Moraceae: } \\
\hline Dorstenia L. & 105 & 46 & 48 & Berg 2001; C. Berg, pers. comm., 2003 \\
\hline \multicolumn{5}{|c|}{ Maclura (including Chlorophora } \\
\hline Gaudich.) & 11 & 2 & 1, East Africa, Madagascar & T 73; C. Berg, pers. comm., 2003 \\
\hline Trophis P. Browne & 9 & 5 & 2, Madagascar, Reunion, Comores & Berg 2001; C. Berg, pers. comm., 2003 \\
\hline \multicolumn{5}{|l|}{ Ochnaceae: } \\
\hline Sauvagesia L. & 32 & 30 S. erecta & 2 S. erecta & T 73; LDD likely; V. Bittrich, pers. comm., 2002 \\
\hline \multicolumn{5}{|l|}{ Olacaceae: } \\
\hline Aptandra Miers & 4 & 3 & 1 & T 73; D. Nickrent, pers. comm., 2002 \\
\hline Heisteria Jacq. & 40 & 37 & 3 & T 73 \\
\hline Ptychopetalum Benth. & 4 & 2 & 2 & Т 73 \\
\hline Menodora Bonpl. & 25 & 22 & 3, South Africa & Т 73 \\
\hline \multicolumn{5}{|l|}{ Orchidaceae: } \\
\hline \multicolumn{5}{|l|}{ Diceratostele Summerh./ } \\
\hline Palmorchis Barb. Rodr. & $30 ?$ & $30 ?$ & 1 D. gabonensis, West Africa & Dressler 1981 \\
\hline Pteroglossaspis Rchb.f. & 5 & 4, Cuba, Argentina & 1, East Africa and Madagascar & $\begin{array}{l}\text { T 73; LDD dispersal by wind at least for } \\
\text { P. ruwenzoriensis }\end{array}$ \\
\hline \multicolumn{5}{|l|}{ Pedaliaceae: } \\
\hline Rogeria Delile & 6 & 1 & 5 & Т 73 \\
\hline \multicolumn{5}{|l|}{ Poaceae: } \\
\hline Ctenium Panz. & 2 & 10 & 10 & T 73; L. Clark, pers. comm., 2002 \\
\hline Echinolaena Desv. & 6 & 5 & 1 & Т 73 \\
\hline Eriochrysis P. Beauv. & $7-8$ & $3-4$ & 4 & T 73 \\
\hline Euclasta Franch. & 3 & $2-3$ & 1, tropical Africa & T 73 \\
\hline Loudetia Steud. & 20 & 1 & 19 & T 73; L. Clark, pers. comm., 2002 \\
\hline Olyra L. & 22 & 22 O. latifolia & 1 O. latifolia & T 73; O. latifolia introduced by man? \\
\hline
\end{tabular}




\begin{tabular}{|c|c|c|c|c|}
\hline Orthoclada P. Beauv. & 2 & 1 & 1, southeast Africa & T 73; L. Clark, pers. comm., 2002 \\
\hline Paratheria Griseb. & 2 & 2 & 1 ? & T 73 \\
\hline Sorghastrum Nash & 12 & 7 & 5 & Т 73 \\
\hline Trachypogon Nees & 3 & 2 & 1 & Т 73 \\
\hline Trichoneura Andersson & 9 & 3, U.S.A., Peru, Galapagos & 6 & Т 73 \\
\hline Willkommia Hack. & 5 & 1, U.S.A.; 1 Argentina & 3 & Т 73 \\
\hline \multicolumn{5}{|l|}{ Polygonaceae: } \\
\hline Symmeria Benth. & 1 & $1 S$. paniculata & 1 S. paniculata, West Africa & Т 73 \\
\hline \multicolumn{5}{|l|}{ Pontederiaceae: } \\
\hline Eichhornia A. Rich. & 5 & 5 & 1 & T 73; Eichhornia crassipes introduced by man? \\
\hline Heteranthera Ruiz \& Pav. & 10 & 7 & 3 & Т 73 \\
\hline \multicolumn{5}{|l|}{ Rapateaceae: } \\
\hline $\begin{array}{l}\text { Maschalocephalus Gilg \& K. } \\
\text { Schum. }\end{array}$ & 1 & $1 \mathrm{M}$. phalus dinklagei & 1 M. dinklagei, West Africa & Givnish et al. 2000, 2004 \\
\hline \multicolumn{5}{|l|}{ Rhizophoraceae: } \\
\hline Cassipourea subgen. Cassipourea & 62 & 9 & Unclear species numbers & $\begin{array}{l}\text { LDD inferred from genetic distances; A. } \\
\text { Schwarzback, pers. comm., } 2002\end{array}$ \\
\hline Rhizophora & 6 & 2 R. mangle & 1 R. mangle, West Africa & $\begin{array}{l}\text { LDD inferred from genetic distances; A. } \\
\text { Schwarzback, pers. comm., } 2002\end{array}$ \\
\hline \multicolumn{5}{|l|}{ Rubiaceae: } \\
\hline Bertiera Aublet & 28 & $\begin{array}{l}2 \text { B. guianensis in east Brazil; } \\
\text { B. bracteosa in Ecuador! }\end{array}$ & 16 & T 73; Andreasen and Bremer 2000 \\
\hline Mitracarpus Schult. \& Schult. f. & 30 & 30 & 1 West Africa and Madagascar & $\begin{array}{l}\text { T 73; M. scaber introduced by man? Bremer and } \\
\text { Manen } 2000\end{array}$ \\
\hline Pentodon Hochst. & $2-3$ & 1 P. pentandrus & 1 P. pentandrus & $\begin{array}{l}\text { T 73; apparently a global weed; Bremer and Manen } \\
2000\end{array}$ \\
\hline Sabicea Aublet & 130 & 40 & 82 & T 73; Bremer and Thulin 1998 \\
\hline \multicolumn{5}{|l|}{ Rutaceae: } \\
\hline Thamnosma Torr. \& Frém. & $6-10$ & 4, also North America & 2, also Socotra & Т 73 \\
\hline \multicolumn{5}{|l|}{ Sapindaceae: } \\
\hline Paullinia L. & $180-200$ & $180-200$ & 1 & Т 73 \\
\hline \multicolumn{5}{|l|}{ Sapotaceae: } \\
\hline $\begin{array}{l}\text { Chrysophyllum including } \\
\text { Gambeya Pierre }\end{array}$ & 25 & 11 & 14 & T 73; Pennington 1990 \\
\hline \multicolumn{5}{|l|}{ Solanaceae: } \\
\hline Lycium $\mathrm{L}$. & 100 & $84 ?$ & 16 South Africa & LDD possible; L. Bohs, pers. comm., 2002 \\
\hline Schwenkia L. & 10 & 10 S. americana & $1 S$. americana & T $73 ; S$. americana introduced by man? \\
\hline \multicolumn{5}{|l|}{ Turneraceae: } \\
\hline Turnera sect. Piriqueta & 19 & 18 & 1 & Т 73 \\
\hline \multicolumn{5}{|l|}{ Ulmaceae: } \\
\hline Celtis L. (subg. Mertensia) & Needs study & Needs study & Needs study & $\begin{array}{l}\text { Berg and Dahlberg 2001; C. Berg, pers. comm., } \\
2003\end{array}$ \\
\hline \multicolumn{5}{|l|}{ Urticaceae: } \\
\hline Phenax Wedd. & 12 & 12 & 1 & $\begin{array}{l}\text { T 73; introduced by man and naturalized in Africa } \\
\text { and Madagascar? }\end{array}$ \\
\hline \multicolumn{5}{|l|}{ Verbenaceae: } \\
\hline Lippia L. & 200 & 185 & 15 & Т 73 \\
\hline \multicolumn{5}{|l|}{ Zingiberaceae: } \\
\hline Renealmia L.f. & 75 & 50 & 25 & T 73; Maas 1977 \\
\hline
\end{tabular}

Sources. Based on Thorne (1973; abbreviated "T 73") and additional sources as indicated. Family circumscriptions follow APG II (2003).

Note. Species numbers are usually only rough estimates because of a dearth of monographic work. Epithets are provided for species occurring on both sides of the Atlantic, sometimes possibly due to anthropogenic introductions. LDD = long-distance dispersal. "Excluded" refers to transfers of species published after the compilation of Thorne (1973). 
models of ocean and wind circulation patterns to test inferred directions and times of dispersal events.

Given that there is only a loose connection between dispersal and permanent establishment of a lineage, it is clear that numerous taxa will need to be compared before one expects patterns to emerge. To augment the limited data from flowering plants, the discussion below therefore includes three particularly well-studied trans-Atlantic animal disjunctions to illustrate the kinds of data that need to be evaluated and as a reminder that plants are not the only organisms that crossed the Atlantic; so did monkeys, rodents, and lizards.

\section{Material and Methods}

Lineages with tropical trans-Atlantic distributions were compiled from the literature, starting with Thorne's (1973) list of 111 genera of seed plants restricted to tropical and temperate America and Africa (including Madagascar and African Islands). The focus on genera centered in South America and Africa (leaving out pantropical genera and taxa at other hierarchical levels) was mainly pragmatic: (1) There is no doubt that plant diaspores are constantly exchanged between Africa, Madagascar, India, and the Malesian region via migratory bird flyways, sea currents, and wind, and the list of taxa disjunct between Africa/Madagascar/Asia accordingly comprises several hundred genera (Thorne 1973). A compilation of such relatively uncontroversial dispersal events would have led far beyond my goal of trying to link inferred dispersal directions and times with surface sea currents and winds in a clearly circumscribed system. (2) The initial focus on genera, while introducing a rank-based constraint into the analysis, is justified by the probability of disjunctions at that level often having explanations postdating the breakup of Africa and South America, i.e., dispersal by water, wind, or birds. Disjunctions involving families will often be attributable to the breakup of Gondwana and those involving species to anthropogenic dispersal (e.g., in pantropical weeds). Wherever available, studies on trans-Atlantic clades at higher or lower hierarchical levels were included (e.g., Melastomeae; Symphonia globulifera), but their number is very small.

Thorne's list of genera was updated via a literature search and input from specialists (named in table 1), who reviewed entries for individual families and added information on ongoing molecular systematic work. Paleoclimatic and oceanographic data came mostly from recent literature. Of key importance was evaluation of the evidence for monophyly of the disjunct genera. Where molecular data suggest that a trans-Atlantic disjunct genus is polyphyletic and that African and South American species are more closely related to species on the same continent than on the opposite continent, this "pushes" disjunction events in the respective lineage further back in time, perhaps to the breakup of West Gondwana. Where molecular data reveal that African or Neotropical species are nested within genera occurring on the opposite continent, this increases the number of lineages for which trans-Atlantic diaspore dispersal may need to be invoked. To detect such nesting (i.e., paraphyly), systematists need to sample widely, and on both sides of the Atlantic, which may present more than logistic problems because many of us tend to be continent specialists and may not have the overview necessary to know which taxa from another continent ought to be included in a study. This difficulty, together with the problems of obtaining material from several continents (with various collecting restrictions), may be at the root of why so little is known about tropical range extensions, be they due to natural or anthropogenic long-distance dispersal.

\section{Results}

Some 110 angiosperm genera in 53 families (table 1) contain species on both sides of the tropical Atlantic. Even though these numbers are almost identical to Thorne's (1973), 16 newly recognized disjunct genera were added and 14 others were dropped because they are no longer considered monophyletic (appendix). The disjunction in the range of one other genus, Genlisea, is no longer seen as the result of long-distance dispersal, but instead is explained by entry from the boreotropics (Jobson et al. 2003).

At present, molecular phylogenetic results (topologies and initial molecular clock datings) are available for 11 transAtlantic disjunct lineages (table 2), namely, Cassipourea, Ceiba pentandra, Commiphora, Elaeis oleifera, Maschalocephalus dinklagei, Pitcairnia feliciana, Raphia, Rhizophora, Symphonia globulifera, Wolffiella welwitschii, and the ancestor of a group of genera in the Melastomeae (references, table 2).

A striking pattern evident from table 2 is that the four dispersals from South America to Africa are all inferred to have involved wind, whereas dispersal from Africa to South America is inferred to have involved sea currents. At least the latter probably is a sampling artifact. Inspection of table 1, which includes all 110 trans-Atlantic disjunct genera, indicates several cases of likely dispersal by water from South America to Africa, namely, Andira, Drepanocarpus, Hernandia, Hymenaea, Sacoglottis, and Thalia (possibly also Cayaponia).

There are two instances of previously unrecognized paraphyletic lineages added to Thorne's (1973) list: the Neotropical Fabaceae Hymenaea includes a species from Africa, Trachylobium verrucosum (Lee and Langenheim 1975), and Neotropical Celtis section Mertensia probably includes some or all of African Celtis (C. C. Berg, personal communication, 2003).

\section{Discussion}

Current understanding of the timing and direction of longdistance dispersal across the Atlantic is still very limited, and complementary studies that would focus on anthropogenic introductions are in their infancy. Studies of possible anthropogenic dispersal in tropical species, perhaps with slave ships or modern transport, could begin with the 108 species of angiosperms spanning the Atlantic (Thorne 1973). Such phylogeographic work, of course, would require population-level sampling. However, with one exception, studies on tropical trans-Atlantic clades so far have sampled single accessions per species on the African and South American continents. The exception is a phylogeographic study of a trans-Atlantic disjunct tree species that includes multiple accessions from both sides of the Atlantic (Dick et al. 2003). 
Table 2

Angiosperm Dispersal across the Tropical Atlantic

\begin{tabular}{|c|c|c|c|c|}
\hline Taxon & $\begin{array}{l}\text { South America } \\
\text { to Africa }\end{array}$ & $\begin{array}{l}\text { Africa to } \\
\text { South America }\end{array}$ & $\begin{array}{l}\text { Inferred means } \\
\text { of dispersal }\end{array}$ & Reference \\
\hline Arecaceae, Elaeis oleifera & $\cdots$ & Recent & Water & W. Hahn, pers. comm., 2002 \\
\hline Arecaceae, Raphia taedigera & .. & Recent & Water & $\begin{array}{l}\text { Urquhart 1997; W. Baker, pers. } \\
\text { comm., } 2003\end{array}$ \\
\hline Bromeliaceae, Pitcairnia feliciana & $8 \mathrm{Ma}$ & $\ldots$ & Wind & Givnish et al. 2004 \\
\hline Burseraceae, Commiphora & $\ldots$ & Recent & ? & Weeks et al. 2004 \\
\hline Clusiaceae, Symphonia globulifera & $\ldots$ & 3 events, all recent & Water & Dick et al. 2003 \\
\hline Lemnaceae, Wolffiella welwitschii & $\ldots$ & $9.8 \mathrm{Ma}, 2$ events & Water & Kimball et al. 2003 \\
\hline Malvaceae, Ceiba pentandra & Recent & $\ldots$ & Wind or anthropogenic & C. Dick, pers. comm., 2003 \\
\hline Melastomataceae, Melastomeae & $11 \mathrm{Ma}$ & $\cdots$ & Wind & Renner and Meyer 2001 \\
\hline $\begin{array}{l}\text { Rapateaceae, Maschalocephalus } \\
\text { dinklagei }\end{array}$ & $6 \mathrm{Ma}$ & & Wind & Givnish et al. 2000, 2004 \\
\hline Rhizophoraceae, Cassipourea & $\cdots$ & Recent & Water & A. Schwarzbach, pers. comm., 2002 \\
\hline Rhizophoraceae, Rhizophora & $\ldots$ & Recent & Water & A. Schwarzbach, pers. comm., 2002 \\
\hline Platyrrhine monkeys & $\cdots$ & $33-35 \mathrm{Ma}$ & Water & $\begin{array}{l}\text { Lavocat } 1980 ; \text { Houle } 1999 ; \\
\text { Nei et al. } 2001\end{array}$ \\
\hline Caviomorph rodents & $\cdots$ & $85 \mathrm{Ma}$ or $43 \mathrm{Ma}$ & $\begin{array}{l}\text { Water, but assumed } \\
\text { source controversial }\end{array}$ & $\begin{array}{c}\text { (43 Ma) Lacovat 1974; (43 Ma) } \\
\text { Huchon and Douzery } 2001 ; \\
\text { (85 Ma) Mouchaty et al. } 2001\end{array}$ \\
\hline Mabuya lizards & $\ldots$ & $9 \mathrm{Ma}$ & Water & Carranza and Arnold 2003 \\
\hline
\end{tabular}

From the current data, it appears that transport by surface sea currents has been responsible for successful dispersals in either direction, while winds seem to have played more of a role in diaspore transport from South America to Africa (tables 1,2). This surprising result (if valid) raises the question whether oceanographic and climatic data indicate different predominant directions of water versus wind currents that would explain these apparent differences in their relative roles in conveying biological material from east to west versus west to east.

\section{Ocean Currents}

The tropical Atlantic's major currents vary in strength with the seasons and comprise a westward-flowing North Equatorial Current (NEC), an eastward-flowing North Equatorial Counter Current (NECC), and a westward-flowing South Equatorial Current (SEC) (fig. 1). Although local surface circulation in the east tropical Atlantic is not yet adequately known (Fratantoni 2001), satellite-tracked surface drifters have shown that water movement is very quick in the equatorial region, with typical speeds approaching $1 \mathrm{~m} \mathrm{~s}^{-1}$. (Ocean near-surface drifter data recorded during the 10-yr world ocean circulation experiment are available from the Atlantic Oceanographic and Meteorological Laboratory/NOAA.)

The high drift speeds in some stretches of the Atlantic agree with information from nautical maps (Houle 1999) that reflect accumulated knowledge from tens of thousands of trans-Atlantic crossings by a range of vessels. The two belts in the tropical Atlantic where surface currents and winds are simultaneously favorable for east to west crossing lie between the Congo delta and Maranhão in Brazil (a band between ca. $5^{\circ} \mathrm{N}$ and $10^{\circ} \mathrm{S}$; fig. 1) and just north of the Senegal River delta and northern Brazil and the Guianas (between $10^{\circ}$ and $30^{\circ} \mathrm{N}$; Houle 1999$)$. Both of these surface currents start from river deltas in Africa. The only surface current running in the opposite direction is the NECC, which, however, originates well off the South American coast (fig. 1) and therefore may not be optimally suited for transporting plant parts from northern South America to West Africa.

It is unlikely that the main direction of these currents has changed since the breakup of West Gondwana (Parrish 1993; K. Nisancioglu, personal communication, 2003). Indeed, Parrish (1993, p. 17) suggests that rafting of organisms between South America and Africa during the Tertiary is "likely to have been predominantly east to west rather than the reverse," in agreement with the data in table 2. Surface current systems arise as a result of horizontal pressure gradients induced by the wind and the Coriolis force. In the central Atlantic, they may have been slightly different during the Eocene warm climates; however, there is no good proxy for wind patterns from Tertiary periods, and present wind fields are therefore used in paleo-ocean models (K. Nisancioglu, personal communication, 2002). During the Miocene, at the time of the shoaling of the Central American seaway, the physical mechanism driving the currents (i.e., the winds) would have been the same as today, and the only part of the surface circulation that is assumed to have been different is that in the immediate vicinity of the closing isthmus. Almost certainly, the two current systems in the northern South Atlantic (the NEC and NECC) would have been the same before and after the closing of the isthmus (K. Nisancioglu, personal communication, 2003).

The extent to which fluctuations in the depth of the Atlantic during the Tertiary narrowed the distance between continents and provided stepping stone islands is controversial. Shortest linear distances between Africa and South America have increased from ca. $1000 \mathrm{~km}$ at $50 \mathrm{Ma}$ to $1900 \mathrm{~km}$ at 


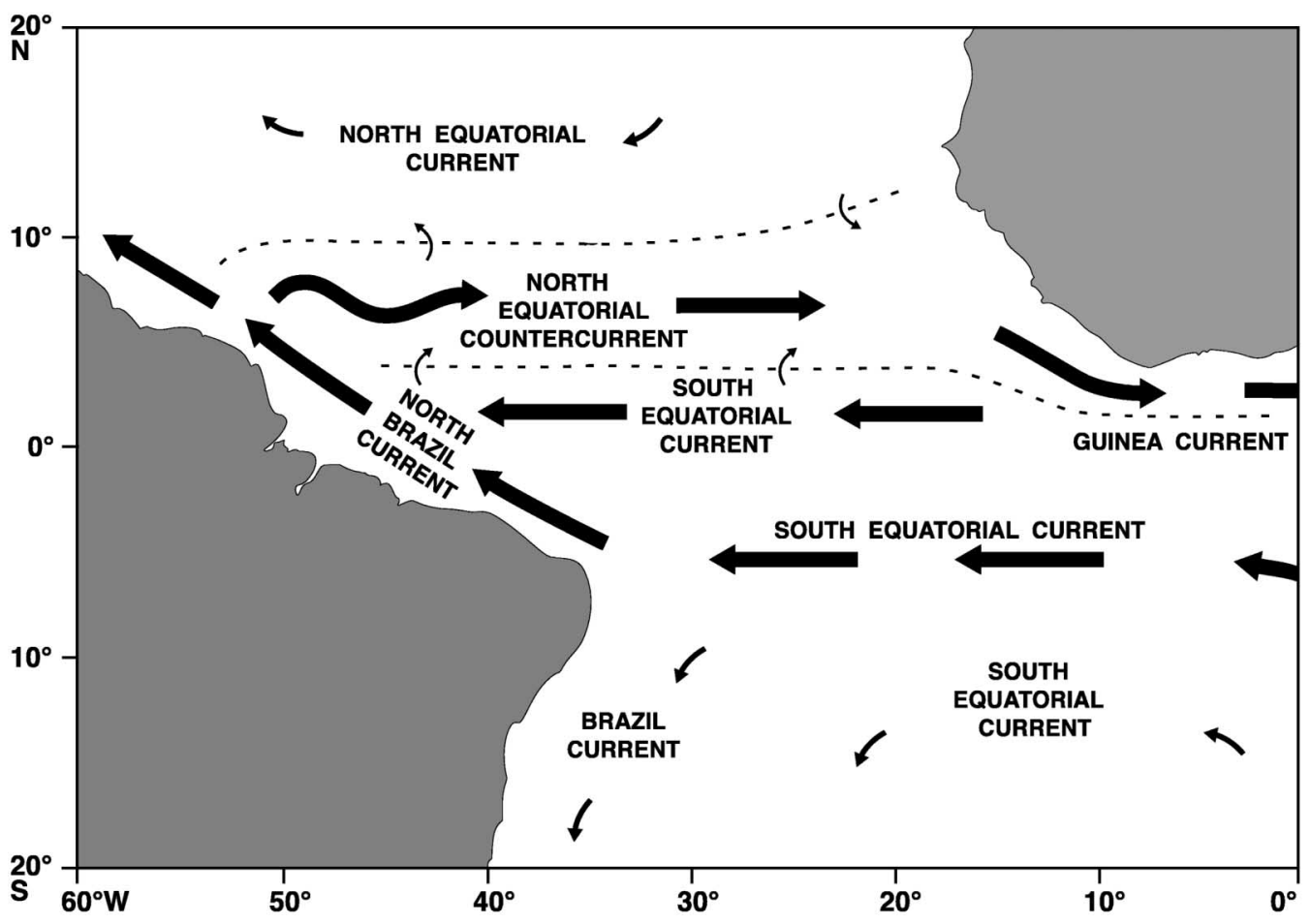

Fig. 1 The major tropical Atlantic surface currents (after Fratantoni et al. 2000)

$30 \mathrm{Ma}$, while "sailing distances," that is, distances covered by surface sea currents and winds, always were ca. $100 \mathrm{~km}$ longer (Houle 1998 tabulates both kinds of distances for various times in the past). Ocean drilling and sonar studies in the southern South Atlantic have shown that the Rio Grande rise (southeast of the coast of Brazil at about the height of Rio de Janeiro) and the western end of the Walvis Ridge (southwest of the coast of Africa at about the height of Cape Town) may have been above water as late as the Oligocene (Parrish 1993; Morley 2000, fig. 12.2), which would have greatly narrowed the distance between the continental coasts. Ocean-floor drilling data are sparser for the northern South Atlantic (Parrish 1993), but the Vema Transverse Ridge, which offsets the Mid-Atlantic Ridge by $320 \mathrm{~km}$ and today is $600 \mathrm{~m}$ below sea level, has been found to be capped by carbonate platforms (reef limestone) that formed at ca. 3-4 Ma (Kastens et al. 1998). Of course, the Mid-Atlantic Ridge itself rises above sea level in several island chains, including St. Paul's Rocks almost exactly on the equator. The species-poor animal and plant floras of these islands may not be indicative of the frequency of biological transport across other regions of the Atlantic, as suggested by inspection of surface drifter trajectories from the World Ocean circulation experiment (see maps in Fratantoni 2001).

Several dispersal events involving vertebrates are relevant to the above discussion of plant dispersal across the Atlantic. They involve the ancestors of Neotropical caviomorph rodents, platyrrhine monkeys, and lizards. The earliest Caviomorpha fossils in South America are 34-32 m.yr. old, and the earliest Platyrrhini fossils are 26 m.yr. old. Both lineages have close relatives in Africa (Mouchaty et al. 2001, but see below; Nei et al. 2001) and neither has fossils in North America, Antarctica, or Australia that would indicate alternative source areas (Houle 1999). Recent reviews (Houle 1998, 1999) of oceanic rafting by small vertebrates (focusing on the tropical Atlantic) tabulate the transport speed of variously shaped objects. Houle's calculations of the times needed for objects to travel from Africa to Brazil or Venezuela are based on nautical charts and incorporate either just the velocity of the surface current or current speed plus wind velocity, as well as a slightly narrower tropical Atlantic at 50, 40, and $30 \mathrm{Ma}$. Floating islands relevant to the postulated migrations of monkeys and rodents probably carried shrubs or trees and therefore were helped along by the trade winds. Without some shade-providing vegetation, it is unlikely that any vertebrates would have survived over a week of sun exposure and dehydration. Records of floating islands, one measuring $60 \mathrm{~m} \times 23 \mathrm{~m}$, with trees as high as $15 \mathrm{~m}$, are reviewed in Houle (1998), although there is no record of such an island far off the coasts of Africa or Brazil. Even so, migration on a floating island appears to be the best explanation for the Oligocene/Miocene arrival of platyrrhines in South America.

For Caviomorpha, exact relationships of South American, African, and Asian lineages are still unclear (cf. Mouchaty et al. 2001 and Huchon and Douzery 2001), but rafting across some water barrier is inferred by all studies. The same holds for several tropical American lizard groups that, according to DNA evidence, arrived by trans-Atlantic dispersal from Africa during the last 10 m.yr., once reaching the American mainland and once the oceanic island of Fernando de Noronha, two journeys each of at least $3000 \mathrm{~km}$ (Carranza and Arnold 2003 and references therein). 


\section{Wind Currents}

It is more difficult to account for dispersal events inferred to have been due to winds blowing from South America to Africa (table 2). So far, four such instances involving Bromeliaceae, Melastomataceae, Rapateaceae, and possibly Malvaceae are suggested by molecular topologies and dating. Westerly surface winds over the central Atlantic $\left(10^{\circ} \mathrm{S}-5^{\circ} \mathrm{N}\right.$, $\left.40^{\circ} \mathrm{W}-0^{\circ} \mathrm{E}\right)$ exist but are subject to significant year-to-year changes. They result from the pressure trough over the Sahara, which in some years turns both northern and southern trade wind systems toward the continent, resulting in the West African monsoon. Westerly wind jets may exceed nearsurface speeds of $10 \mathrm{~m} \mathrm{~s}^{-1}$ and even $15 \mathrm{~m} \mathrm{~s}^{-1}$ and may extend across the entire Atlantic basin, although they very rarely, for example, on August 17, 1999, occur over the South American coast (Grodsky et al. 2003; S. A. Grodsky, personal communication). These wind jets appear in May and persist through September, with their latitudinal position following the meridional migration of the Intertropical Convergence Zone (ITCZ). Years with strong near-surface westerly winds tend to correlate with tropical storms and hurricanes over the western Atlantic (Grodsky et al. 2003) and with African rainfall patterns (Jury et al. 2002). Storms also occasionally blow in the other direction (from Africa to South America), and dust is regularly swept out over the Atlantic Ocean from the Sahara Desert, sometimes blowing all the way to North and South America (http://earthobservatory. nasa.gov/). Even desert locusts, Schistocerca gregaria, are occasionally (e.g., in 1950 and 1988) transported alive from Africa to Surinam, Guyana, or the West Indies (Tipping 1995).

\section{Transport on Birds}

Dispersal of seeds across the tropical Atlantic by aquatic birds, for example, ducks, is an oft-mentioned possibility, most explicitly perhaps by Iltis (1967), who adduces the ranges of trans-Atlantic disjunct duck sister species as an argument in favor of past trans-Atlantic seed dispersal by these ducks. However, there are no bird migratory routes across the Atlantic, and the cattle egret, Bubulcus ibis, which apparently flew over the Atlantic sometime around 1880, established in Brazil, and from there spread to North America, remains the only documented case of a trans-Atlantic colonization event by a bird (Terres 1991). The cattle egret feeds on insects (Terres 1991), and I have located no records of seeds it may transport. Marine birds rarely if ever eat seeds or fruits, and frugivorous land birds usually vacate their guts frequently (every few minutes; Snow and Snow 1988; White and Stiles 1990). A fruit-eating bird blown offshore by a storm is very unlikely to retain gut content across the Atlantic. This leaves the possibilities of seeds sticking to the feet or feathers of marine or shore birds, which, however, requires that a plant species occurs in the habitats frequented by these birds and has the necessary morphological adaptations (Carlquist 1981). That land birds (and seeds) nevertheless have occasionally reached the Mid-Atlantic islands is shown by endemic bird species, such as on Tristan da Cunha, which has five land bird species, a rail, a moorhen, a thrush, and two buntings (Sibley and Monroe 1990).

\section{Conclusion}

Tangled plant parts ("floating islands") are constantly carried out into the tropical Atlantic from the deltas of the Congo, Senegal, and Amazon rivers, and some enter the conveyer belt-like currents that transport debris (including plastic trash; Barnes 2002) in either direction across the Atlantic. Because of their speed, equatorial currents can transport larger floating objects with wind-exposed surfaces across the Atlantic in less than 2 weeks, and transport was probably faster across the narrower Atlantic of the Early Tertiary. Successful dispersal of diaspores by wind or stuck on birds appears to be less common. It is also possible that minute seeds, such as those of Melastomataceae, which are known to be abundant in tropical soils (Dalling et al. 1998), crossed the Atlantic in soil stuck to drifting vegetation rather than being carried by exceptional westerly winds or hurricanes. Indeed, if monkeys and rodents arrived on a uniquely successful floating island, that same island would have brought lots of seeds, insects, and lower organisms.

Judging from the slow increase in our understanding of timing and direction of successful dispersal events across the Atlantic over the 30 years since Robert Thorne's review of the topic in 1973, an overly optimistic outlook is not warranted. However, empirical and model-derived oceanographic and climatic data now make it easier for botanists than it was in the 1970s to envision rapid Atlantic crossings along specific sea and wind currents, sometimes followed by successful establishment of a lineage.

\section{Acknowledgments}

I thank Robert Thorne and the participants in the symposium on tropical disjunctions for their inspiration; the colleagues listed in table 1 for information on tropical transAtlantic disjunctions; and Robert Ricklefs, Andreas Groeger, Andrea Weeks, and an anonymous reviewer for comments on the manuscript.

\section{Appendix}

Genera previously (e.g., Thorne 1973) seen as occurring on both sides of the Atlantic but now seen as polyphyletic include the following: (1) Schaueria Nees, sole African species excluded (L. McDade, personal communication); (2) Thyrsodium Benth., sole African species excluded (A. Miller, personal communication); (3) Chrysocoma L. and (4) Tarchonanthus L., in both cases, Neotropical species excluded (J. Panero, personal communication); (5) Acioa Aublet, African species transferred into Dactyladenia (genera may be sister groups; C. Morton, personal communication); (6) Vismia Vand., African species transferred to Harungana (genera may be sister groups; M. Gustafsson, personal communication); (7) Paepalanthus Mart., African species excluded; 
(8) Savia Willd., African species excluded; (9) Conceveiba Aublet, both African species transferred to Aubletiana (Murillo 2000); (9) Newtonia Baill., Neotropical species excluded; (10) Swartzia Schreb., African species transferred into Bobgunnia J. H. Kirk. \& Wiersema (Ireland et al. 2000); (11) Hoffmannseggia, the three African species transferred to Pomaria (Simpson and Lewis 2003; Simpson et al. 2003); (12) Landolphia P. Beauv., the two Neotropical species now recognized as a separate genus Pacouria (M. Fallen, personal communication); (13) Sphaeralcea A. St.-Hil., African species excluded (C. Bayer, personal communication); (14) Trymatococcus Poepp. \& Endl., African species transferred into Dorstenia (C. C. Berg, personal communication).

\section{Literature Cited}

Albert VA, L Struwe 1997 Phylogeny and classification of Voyria (saprophytic Gentianaceae). Brittonia 49:466-479.

Anderson C 1997 Monograph of Stigmaphyllon (Malpighiaceae). Syst Bot Monogr 51:1-313.

2001 The identity of two water-dispersed species of Heteropterys (Malpighiaceae): H. leona and H. platyptera. Contrib Univ Mich Herb 23:35-47.

Anderson WR 1990 The origin of the Malpighiaceae: the evidence from morphology. Mem N Y Bot Gard 64:210-224.

Andreasen K, B Bremer 2000 Combined phylogenetic analysis in the Rubiaceae-Ixoroideae: morphology, nuclear and chloroplast DNA data. Am J Bot 87:1731-1748.

APG II 2003 An update of the Angiosperm Phylogeny Group classification for the orders and families of flowering plants. Bot J Linn Soc 141:399-436.

Balkwill MJ, K Balkwill 2002 A preliminary analysis of distribution patterns in a large, pantropical genus, Barleria L (Acanthaceae). J Biogeogr 25:95-110.

Barnes DKA 2002 Invasions by marine life on plastic debris. Nature 416:808-809.

Berg CC 2001 Moreae, Artocarpeae, and Dorstenia (Moraceae), with introductions to the family and Ficus and with additions and corrections to Flora Neotropica Monograph 7. Flora Neotrop Monogr 53:1-346.

Berg CC, SV Dahlberg 2001 A revision of Celtis subg. Mertensia (Ulmaceae). Brittonia 53:66-81.

Bremer B, JF Manen 2000 Phylogeny and classification of the subfamily Rubioideae (Rubiaceae). Plant Syst Evol 225:43-72.

Bremer B, M Thulin 1998 Collapse of Isertieae, re-establishment of Mussaendeae, and a new genus of Sabiceeae (Rubiaceae): phylogenetic relationships based on $r b c L$ data. Plant Syst Evol 211:71-92.

Carlquist S 1981 Chance dispersal. Am Sci 69:509-516.

Carranza S, EN Arnold 2003 Investigating the origin of transoceanic distributions: mt DNA shows Mabuya lizards (Reptilia, Scincidae) crossed Atlantic twice. Syst Biodivers 1:275-282.

Chanderbali AS, H van der Werff, SS Renner 2001 The relationships and historical biogeography of Lauraceae: evidence from the chloroplast and nuclear genomes. Ann Mo Bot Gard 88:104-134.

Dalling JW, MD Swaine, NC Garwood 1998 Dispersal patterns and seed bank dynamics of pioneer trees in moist tropical forest. Ecology 79:564-578.

Davis CC, CD Bell, S Mathews, MJ Donoghue 2002 Laurasian migration explains Gondwanan disjunctions: evidence from Malpighiaceae. Proc Natl Acad Sci USA 99:6833-6837.

Dick CW, K Abdul-Salim, E Bermingham 2003 Molecular systematic analysis reveals cryptic Tertiary diversification of a widespread tropical rainforest tree. Am Nat 162:691-703.

Doerrstock S, R Seine, S Porembski, W Barthlott 1996 First record of Utricularia juncea (Lentibulariaceae) for tropical Africa. Kew Bull 51:579-583.

Dressler RL 1981 The orchids: natural history and classification. Harvard University Press, Cambridge, Mass.

Engler A 1905 Ueber floristische Verwandtschaft zwischen dem tropischen Afrika und Amerika, sowie ueber die Annahme eines versunkenen brasilianischen-aethiopischen Kontinentes. Sitzungsber K Preuss Akad Wiss Phys Math Kl 6:179-231.

Esser H-J 1999 Taxonomic notes on Neotropical Maprounea Aublet (Euphorbiaceae). Novon 9:32-35.

Fratantoni DM 2001 North Atlantic surface circulation during the 1990s observed with satellite-tracked drifters. J Geophys Res 106: 22067-22093.

Fratantoni DM, WE Johns, TL Townsend, HE Hurlburt 2000 Lowlatitude circulation and mass transport pathways in a model of the tropical Atlantic Ocean. J Phys Oceanogr 30:1944-1966.

Givnish TJ, TM Evans, ML Zjhra, PE Berry, KJ Sytsma 2000 Molecular evolution, adaptive radiation, and geographic diversification in the amphiatlantic family Rapateaceae: evidence from $n d b F$ sequence data. Evolution 54:1915-1937.

Givnish TJ, KC Millam, TM Evans, JC Hall, JC Pires, PE Berry, KJ Sytsma 2004 Ancient vicariance or recent long-distance dispersal? inferences about phylogeny and South American-African disjunctions in Rapateaceae and Bromeliaceae based on $n d h \mathrm{~F}$ sequence data. Int J Plant Sci 165(suppl):S000-S000.

Good R 1964 The geography of flowering plants. Wiley, New York. Grodsky SA, JA Carton, S Nigam 2003 Near surface westerly wind jet in the Atlantic ITCZ. Geophys Res Lett, Pap 2003 GL01786.

Gunn CR 1968 Stranded seeds and fruits from the southeastern shore of Florida. Gard J 18:43-54.

Hepper FN 1965 Preliminary account of the phytogeographic affinities of the flora of west tropical Africa. Webbia 19:593-617.

Houle A 1998 Floating islands: a mode of long-distance dispersal for small and medium-sized terrestrial vertebrates. Divers Distrib 4: 201-216.

- 1999 The origin of platyrrhines: an evaluation of the Antarctic scenario and the floating island model. Am J Phys Anthropol 109:541-559.

Huchon D, EJP Douzery 2001 From the Old World to the New World: a molecular chronicle of the phylogeny and biogeography of hystricognath rodents. Mol Phylogenet Evol 20:238-351.

Iltis HH 1967 Studies in the Capparidaceae. XI. Cleome afrospinosa, a tropical African endemic with Neotropical affinities. Am J Bot 54: 953-962.

Ireland H, RT Pennington, J Preston 2000 Molecular systematics of the Swartzieae. Pages 217-232 in P Herendeen, A Bruneau, eds. Advances in legume systematics. Pt 9. Royal Botanic Gardens, Kew.

Jobson RW, J Playford, KM Cameron, VA Albert 2003 Molecular phylogenetics of Lentibulariaceae inferred from plastid rps 16 intron and $t r n \mathrm{~L}-\mathrm{F}$ DNA sequences: implications for character evolution and biogeography. Syst Bot 28:157-171.

Jury MR, DB Enfield, J-L Mélice 2002 Tropical monsoons around Africa: stability of El Niño-Southern Oscillation associations and links with continental climate. J Geophys Res 107:1-17.

Kastens K, E Bonatti, D Caress, G Carrara, O Dauteuil, G FruehGreen, P Tartarotti, M Ligi 1998 The Vema Transverse Ridge (Central Atlantic). Mar Geophys Res 20:533-556.

Kimball RT, DJ Crawford, DH Les, E Landolt 2003 Out of Africa: molecular phylogenetics and biogeography of Wolffiella (Lemnaceae). Biol J Linn Soc 79:565-576. 
Kubitzki 1969 Monographie der Hernandiaceen. Bot Jahrb 89: 78-148.

Lavin M, M Luckow 1993 Origins and relationships of tropical North America in the context of the boreotropics hypothesis. Am J Bot 80:1-14.

Lavin M, M Thulin, J-N Labat, T Pennington 2000 Africa, the odd man out: molecular biogeographic studies of dalbergioid legumes (Fabaceae) suggest otherwise. Syst Bot 25:449-467.

Lavocat R 1974 What is an hystricomorph? Pages 7-20 in IW Rowlands, BJ Weir, eds. The biology of hystricomorph rodents. Symposium of the Zoological Society of London, vol 34. Academic Press, London.

1980 The implications of rodent paleontology and biogeography to the geographical sources and origin of platyrrhine primates. Pages 103-122 in RL Ciochon, AB Chiarelli, eds. Evolutionary biology of the New World monkeys and continental drift. Plenum, New York.

Lee YT, JH Langenheim 1975 Systematics of Hymenaea L. Univ Calif Publ Bot 69:1-109.

Maas PJM 1977 Renealmia (Zingiberaceae-Zingiberoideae). Flora Neotrop Monogr 18:1-161.

Manchester S 1999 Biogeographical relationships of North American Tertiary floras. Ann Mo Bot Gard 86:472-522.

Meyer J-Y 2000 Preliminary review of the invasive plants in the Pacific islands (SPREP Member Countries). Pages 85-114 in G Sherley, ed. Invasive species in the Pacific: a technical review and draft regional strategy. South Pacific Regional Environment Programme, Apia, Western Samoa.

Morley RJ 2000 Origin and evolution of tropical rain forests. Wiley, New York.

Mouchaty SK, F Catzeflis, A Janke, U Arnason 2001 Molecular evidence of an African Phiomorpha-South American Caviomorpha clade and support for Hystricognathi based on the complete mitochondrial genome of the cane rat (Thryonomys swinderianus). Mol Phylogenet Evol 18:127-135.

Muñoz J, AM Felicísimo, F Cabezas, AR Burgaz, I Martínez 2004 Wind as a long-distance dispersal vehicle in the Southern Hemisphere. Science 304:1144-1147.

Murillo R 2000 Novedades en la tribu Alchornae [sic] (Euphorbiaceae). Rev Acad Colomb Cienc Exper Fis Nat 24:359-370.

Nei M, P Xu, G Glazko 2001 Estimation of divergence times from multiprotein sequences for a few mammalian species and several distantly related organisms. Proc Natl Acad Sci USA 98:2497-2502.

Parrish JT 1993 The paleogeography of the opening South Atlantic. Pages 8-41 in W George, R Lavocat, eds. The Africa-South America connection. Clarendon, Oxford.

Pennington RT 1990 Sapotaceae. Flora Neotrop Monogr 52:1-770. 2003 Monograph of Andira (Leguminosae-Papilionoideae). Syst Bot Monogr 64:1-143.

Renner SS, G Clausing, K Meyer 2001 Historical biogeography of Melastomataceae: the roles of Tertiary migration and long-distance dispersal. Am J Bot 88:1290-1300.

Renner SS, K Meyer 2001 Melastomeae come full circle: biogeographic reconstruction and molecular clock dating. Evolution 55: $1315-1324$.
Sibley CG, BL Monroe Jr 1990 Distribution and taxonomy of birds of the world. Yale University Press, New Haven, Conn.

Simpson BB 1998 A revision of Pomaria (Fabaceae) in North America. Lundellia 1:46-71.

1999 A revision of Hoffmannseggia (Fabaceae) in North America. Lundellia 2:14-54.

Simpson BB, LL Larkin, A Weeks 2003 Progress towards resolving the relationships of the Caesalpinia group (Caesalpinieae: Caesalpinioideae: Fabaceae). Pages 123-148 in B Klitgaard, A Bruneau, eds. Advances in legume systematics X. Higher level systematics and biogeography. Royal Botanic Garden, Kew, Richmond.

Simpson BB, GP Lewis 2003 New combinations in the genus Pomaria. Kew Bull 58:175-184.

Smith AC 1981 Flora vitiensis nova: a new flora of Fiji. National Tropical Botanic Garden, Lawai, Kauai, Hawaii.

Snow BK, DW Snow 1988 Birds and berries: a study of an ecological interaction. Poyser, Calton, England.

Struwe L, JW Kadereit, J Klackenberg, S Nilsson, M Thiv, KB von Hagen, VA Albert 2002 Systematics, character evolution, and biogeography of Gentianaceae, including a new tribal and subtribal classification. Pages 21-309 in L Struwe, VA Albert, eds. Gentianaceae: systematics and natural history. Cambridge University Press, Cambridge.

Taylor P 1989 The genus Utricularia: a taxonomic monograph. Kew Bull 79:613-622.

Terres JK 1991 The Audubon Society encyclopedia of North American birds. Random House, New York.

Thorne RF 1972 Major disjunctions in the geographic ranges of seed plants. Q Rev Biol 47:365-411.

1973 Floristic relationships between tropical Africa and tropical America. Pages 27-47 in BJ Meggers, WD Duckworth, eds. Tropical forest ecosystems in Africa and South America: a comparative review. Smithsonian Institution, Washington, D.C.

1996 Some guiding principles of biogeography. Telopea 6: $845-850$.

Tiffney BH 1985a Perspectives on the origin of the floristic similarity between eastern Asia and eastern North America. J Arnold Arbor Harv Univ 66:73-94.

- $1985 b$ The Eocene North Atlantic land bridge: its importance in Tertiary and modern phytogeography of the Northern Hemisphere. J Arnold Arbor Harv Univ 66:243-273.

Tipping C 1995 The longest migration. Pages 23-25 in TJ Walker, ed. University of Florida book of insect records. University of Florida, Gainesville.

Urquhart GR 1997 Paleoecological evidence of Raphia in the pre-Columbian Neotropics. J Trop Ecol 14:783-791.

Weeks A, DC Daly, BB Simpson 2004 Phylogenetic relationships and historical biogeography of the Burseraceae based on nuclear and chloroplast sequence data. Mol Phylogenet Evol (in press).

White DW, EW Stiles 1990 Co-occurrences of foods in stomachs and feces of fruit-eating birds. Condor 92:291-303.

Wolfe JA 1975 Some aspects of plant geography of the Northern Hemisphere during the late Cretaceous and Tertiary. Ann Mo Bot Gard 62:264-279. 